\title{
ENVIRONMENTAL ACCOUNTING - A TOOL USED BY THE ENTITY FOR DETERMINING ENVIRONMENTAL COSTS
}

\author{
Nicolae Todea ${ }^{1}$ \\ Ionela Cornelia Stanciu ${ }^{2}$ \\ Ana Maria Joldoş (Udrea $)^{3}$
}

ABSTRACT: This paper wants to make a fundamental contribution to current and recently started a debate in the accounting profession and beyond. Internationally, the accounting profession, influenced by a variety of views and broader contextual forces, began to really take into account how environmental regulation of accounting. Historically speaking, the accounting was limited, most often in his reflections on the resources represented by property and financial entities. This has become less appropriate, being left out of accounting reflecting the "costs" important, such as environmental, social, etc. Which were not present in the financial statements of entities, it is because entities do not "pay" anything for the environment, and rather less on social issues. This does not mean that society as a whole; do not support these "costs". The emergence of environmental accounting dating back to 1970, interest in this area increased considerably, from managers to give greater importance to environmental issues.

Key words: Environmental Protection, Environmental accounting, Environmental costs, Protection

JEL codes: $M 41,013$

\section{Introduction}

Accounting is required to submit various types of user information on the financial position and performance of entities in the management of resources at their disposal. In recent decades a growing number of entities give great importance to environmental issues and their reflection by accounting, either under the influence of administrative regulations or because of their information needs. In certain circumstances, for certain fields, they can have a significant impact on the financial statements, and that of their users. Green accounting has been around for two decades. As in all cases, environmental management accounting is a tool to inform managers about the environmental costs, to quantify the environmental effects of the entity.

\section{Research Methodology}

The methodology is a complex word (concept), etymologically composed of method's and logos which mean "method" and "science", in Greek, and free translation "science method", the science of conception, choice and use of method in the investigation process of economic phenomena. The research methodology is the theory and practice methods, an activity that is studying the essence, nature, status, definition, classification, etc. the construction of explanatory models.

The need for scientific research in accounting is particularly important today, more than that pluridisciplinarity in accounting research is necessary and sometimes profitable. Scientific research is

\footnotetext{
${ }^{1}$ University 1 Decembrie 1918 Alba Iulia, Nicolae Iorga Street, no.11-13, ntodea@uab.ro

${ }^{2}$ University Valahia Targoviste, Lt. Ion Stancu Street, no. 34-35, s_ionela09@yahoo.com

${ }^{3}$ University Valahia Targoviste, Lt. Ion Stancu Street, no. 34-35, anajoldos232004@ yahoo.com
} 
necessary to seek and find solutions or answers to immediate problems and to achieve reasonable theorizing issues to the environmental accounting, the expenditure of the environment, reporting. The main objectives considered in preparing this article consisted of a stage presentation of knowledge in the field of environmental accounting, presentation of concepts related to the concept of environmental expenses and costs, identification of different criteria for the classification of environmental costs, presentation of specific accounting treatment of environmental expenditure, presentation of environmental costs in Romania for the years 2007 and 2008.

The scientific approach is based on information from literature and specialized national European and international practice regarding environmental accounting and environmental specific treatment costs. In this article we used methods of research like documentation, comparison, analysis, synthesis, in order to achieve the proposed objectives.

\section{The current state of knowledge in the field of environmental accounting}

Environmental issues have found a reflection in the accounts only in the last part of the twentieth century. The chronology of important developments in environmental accounting and environmental issues reflected in the accounts we find at Ienciu (2009) which presents the following rhythms:

$\rightarrow$ Period 1971-1987: represents the beginning of the first environmental accounting research due to the importance that begins to gain this area. The first period takes into account the literature in this field through studies treating social and environmental accounting in the same way. Since the early 80s, surveys suggest that the separation of environmental accounting and social accounting is starting, due to increased interest in environmental reporting compared to the social. Also in this period begin to appear accounting books dealing with aspects of social and environmental accounting. According to research from this period, environmental auditing and environmental management accounting were not treated separately. As a first step in the development of environmental accounting the articles published on this subject have been in a small number, just like the regulations regarding environmental accounting.

$\rightarrow$ Period 1988-1994: the problem of environmental accounting is becoming an area of interest. In this period of increased interest of researchers for this area, managers and even accountants begin to pay attention to the problem of environmental accounting. It also increases research in environmental accounting terms at the expense of research on social accounting. In this period, the concepts of sustainability and environmental audit begin to interest the users. There were a number of books and articles that dealt with the environmental accounting, environmental accounting showing the state of knowledge both within universities and in the accounting. The progress in environmental accounting regulations is slow, but much faster in comparison with that of social accounting.

$\rightarrow$ Period 1995-2001: environmental accounting at both theoretical and practical level starts to address on a large scale especially in developed countries. The number of studies in this period begins to grow; this period can be called "the cornerstone" of accounting environment. Sub domains of environmental accounting begin to develop, such as environmental costs, environmental management accounting and environmental auditing. The concept of environmental audit occurred in the USA at the beginning of the ' 80 for evaluating ecological performances of some units in the oil field and chemical industry. So as to avoid the payments incurred by environmental pollution, buyers systematically proceeded to acquisitions from the units that implemented environmental protection policies (Bețianu Leontina et all, 2008). Environmental accounting researchers are beginning to give greater importance to this area, begin to increase significantly the number of studies, environmental reports of remain the main sub domain researchers treated. This sub domain begins to interest due to the implementation of standards for environmental management, which contain a part of the audit or verification. 
$\rightarrow$ Period 2002-present: there is a widening of this area of research in numerous developing countries including Romania. At the international level are issued guidelines on reporting environmental information and regulations appearing in the accounting environment. The number and quality of articles on environmental accounting continues to grow. Year 2002 is the year that in Romania the conceptual studies are beginning to appear. Studies in environmental accounting are becoming more numerous, more extensive, outstanding contributions to the development of this field of research have: C. Deegan, O'Donovan, Freedman and Stagliano, Cormier, Möbus, Gray, Chatterge, Aerts and Cornier. Regarding the Romanian researchers, we include here the study by Lungu (Lungu et all, 2008), which proposes "new approach" for corporate reporting and report of social and environmental information. In Romania, there are studies of authors: Caraiani, Dumitrana, Jianu Tăbără, and Nuţă, Ienciu, Cenuşă, which present the environmental accounting as an system composed of three parts: the reporting, the management and the environmental audit. Environmental management accounting experiences a separate development, both in terms of published studies and the quality and diversity of concepts and theories discussed. In Romania, there are theoretical papers which treat environmental costs (Dumitrana, 2005), analysis of the product life cycle (Crețu, 2004), environmental performance and its implications on the financial performance of the entity (Crețu, 2004; Caraiani, 2007; Bonaci and Ienciu, 2007). The environmental audit is treated increasingly more in this period, with the first work in Romania dealing with this problem (Borza, 2007). Involvement of Romania's accounting in the business of environmental protection is even stronger with the entry into force on January 1, 2010 of the Order 3055/2009 for approving the Accounting Regulations in accordance with European directives, so in the chart of accounts, a new account is inserted, account 652 "Expenditure on environmental protection. With this account are kept environmental protection expenditure recorded in the relevant period, for example, environmental taxes paid, and the certificates of emissions of greenhouse gases effect purchased.

From the presented it results that research into environmental accounting have come to the forefront of accounting research, outpacing other chapters, such as social accounting, given the importance of environmental issues on the community. Environmental reports remain an area of interest for researchers, but other research subfields also have interest from researchers, namely, environmental management accounting and environmental auditing.

\section{Accounting involvement in environmental protection activities}

Constant degradation of the environment and the growing number of environmental disasters has caused environmental problems to have a greater importance. Integrating environmental issues in life requires entities to consider them at economic and legal, accounting, financial, and technical level (Lafontaine, JP, 2002). In economic terms taking into account environmental parameters in the cost of services or products, enable entities, on the one hand to rationalize energy consumption of natural resources, achieving substantial savings and, secondly, to meet the requirements of environmental compliance consumer health. Legal consideration of environmental risks is required to undertake the responsibility of the entity. This responsibility rises from failure to comply with environmental legislation and may result in administrative sanctions, civil and / or criminal. From the accounting and financial point of view, recording of environmental costs and determining environmental costs generated by the entity and related financial disclosure is way of evaluating the performance of work (Bețianu L., 2008).

The question is: Which department of the entities would be most suitable for the management of environmental information? A certified public accountant from Bulgaria, Dimiter Jeliazkov, in a study called "Accounting can and should be involved in environmental protection", says that" the only subdivision that could meet this challenge, is the accounting department, reflected as financial and 
economic condition of the entity and changes of these conditions in the most comprehensive and multilateral way "(D. Jeliazkov, 2009, p. 52). He proposes to develop an international standard for environmental accounting, to implement a uniform solution across the globe titled "Reporting on environmental regeneration" aimed at determining the organization and implementation of reporting on environmental regeneration within the entities that pollute, and those who consume natural resources. In Bulgaria there is such a standard which deals with environmental issues and lines of coordination to be put into application, but did not become operational due to lack of interest from both, the entities that pollute, and the competent governmental bodies.

As we have noted, the involvement of Romania in accounting for environmental protection work has found a reflection with the accounting regulations in accordance with European Directives, applicable from 1 January 2010, which included the chart of accounts 652 "Environmental Protection Expenditure. In our opinion only this account is not enough, because you can't separate elements that reflect the cost of materials, wages, etc.

\section{Environmental accounting treatment applicable to environmental costs}

No matter what their activity is, entities must be within the general rules of an open democratic society; one of the most important rules of democracy is transparency. Transparency requires activity "in daylight" or "sight". From this point of view, the entities cannot hide behind secrecy, at least some of their aspects. They are forced to provide information about aspects of their activities in order to allow control of the company on these issues (Todea N., 2009). From the aspects of the entities activities are detaching the aspects related to the economical and financial activity. Such aspects concern how to obtain funding necessary to conduct normal business conditions, the use of these funds, their efficiency, entities providing such information to various categories of users, including public, the result of the existence and operation of an economically information system. The idea is drawn from the international accounting standards, namely IFRS which show that "the objective of financial statements is to provide information about the financial position, financial performance and changes of the financial position of an entity; this information is useful to a broader sphere of users in making economic decisions "(IFRS, 2007).

An important aspect of environmental accounting refers to the recognition of the environmental costs. Obviously this requires defining environmental costs. Such a definition is found in international and European accounting rules. According to the IASB and the FASB, environmental costs are determined environmental costs, which resulted in a benefit that has expired and which is detailed along with income in the income statement.

Recommendation of CE, 453/2001, defines environmental costs as "those costs to prevent, reduce or recover damages that the entity has caused or is likely to cause on the environment as a result of its activities. These include prevention, elimination or reduction of waste and wastewater, air emissions, treatment of contaminated soil, groundwater, noise and vibration levels, the landscape changes, research and innovation of products and cleaner production processes, control of environmental quality".

Canadian Institute of Chartered Accountants (CICA, 1998) present environmental costs as environmental costs which generate, directly or indirectly benefits of the current period, the period in which they occur, providing a series of details in this regard. Thus we have:

$\rightarrow$ Costs generating direct benefits of the current period: expenditure on waste treatment and monitoring, recovery or cleanup costs associated with current business of the entity;

$\rightarrow$ Indirect costs which generates the current period's benefits: the costs of administrative activities, compliance, evaluation and environmental audit, courses and seminars related to staff training on environmental protection; 
$\rightarrow$ Costs regarded as losses for the period: costs that do not generate future economic benefits that cannot be capitalized (costs related to research performed to design cleaner products and processes, costs of participation in recycling programs), costs related to activities undertaken but that generated a benefit that expired (cost recovery and cleaning of polluted land), costs that have not generated any benefit (fines, penalties, failure to comply with environmental regulations and legislation).

As shown in the list above, we can see that the costs of penalties and fines for failure to comply with environmental legislation are not included in the environmental category. In our opinion they should be part of the environmental costs, at least in terms of the sanctioned entity.

The National Institute of Statistics, at the macroeconomic level, reflect environmental costs of financing environmental flows and include payments for economic activities aimed at production of specific services to prevent, reduce or control environmental damage. They are grouped into: investment and running costs which in turn include internal current expenditure (salaries and social security contributions, consumption of raw materials, fuel, energy, water and other auxiliary materials, expenses for research and development, training, information) and current external costs (costs of environmental protection services purchased from third parties and environmental taxes paid). According to the sources, expenditure in this category in 2007 and 2008 in Romania is as follows:

Table no. 1

\section{Expenditure for environmental protection sectors and categories expenditure in 2007 and 2008}

- Thousand lei-

\begin{tabular}{|c|c|c|c|c|c|c|c|c|}
\hline \multirow{4}{*}{ Sectors } & \multirow{3}{*}{\multicolumn{2}{|c|}{ Total expenses }} & \multicolumn{6}{|c|}{ Which } \\
\hline & & & \multirow{2}{*}{\multicolumn{2}{|c|}{ Investment }} & \multicolumn{4}{|c|}{ Current expenditure } \\
\hline & & & & & \multicolumn{2}{|c|}{ internal } & \multicolumn{2}{|c|}{ external } \\
\hline & 2007 & 2008 & 2007 & 2008 & 2007 & 2008 & 2007 & 2008 \\
\hline $\begin{array}{l}\text { Non-specialist } \\
\text { producers }\end{array}$ & 4.516 .525 & 2.743 .422 & 1.550 .499 & 1.329 .980 & 2.153 .762 & 913.847 & 812.264 & 499.595 \\
\hline $\begin{array}{l}\text { Forestry, } \\
\text { logging and } \\
\text { related services }\end{array}$ & 143.087 & 36.976 & 117.024 & 12.547 & 23.799 & 15.892 & 2.264 & 8.537 \\
\hline $\begin{array}{l}\text { Mining and } \\
\text { quarrying }\end{array}$ & 1.336 .006 & 635.420 & 292.874 & 380.742 & 771.532 & 120.174 & 271.600 & 134.504 \\
\hline Manufacturing & 1.873 .122 & 1.478 .540 & 788.268 & 667.734 & 750.615 & 550.167 & 334.239 & 260.639 \\
\hline $\begin{array}{l}\text { Supply, } \\
\text { electricity, } \\
\text { gas and hot } \\
\text { water }\end{array}$ & 818.851 & 468.199 & 312.143 & 240.773 & 354.449 & 153.351 & 152.259 & 74.075 \\
\hline Construction & 345.459 & 124.287 & 40.190 & 28.184 & 253.367 & 74.263 & 51.902 & 21.840 \\
\hline $\begin{array}{l}\text { Specialized } \\
\text { producers }\end{array}$ & 8.328 .234 & 7.039 .354 & 1.716 .516 & 1.048 .084 & 5.637 .738 & 5.487 .074 & 973.980 & 504.196 \\
\hline $\begin{array}{l}\text { Public } \\
\text { Administration }\end{array}$ & 3.633 .332 & 2.914 .520 & 1.635 .463 & 1.296 .891 & 939.424 & 867.226 & 389.368 & 224.969 \\
\hline
\end{tabular}

Source: www.insse.ro

In 2008, expenditure on environmental protection at national level was approximately 14.3 billion lei, representing approximately $2.8 \%$ of GDP compared to $2.7 \%$ in 2007 . The share of environmental investment specialist producers represented $35.0 \%$ of total investments, followed by public administration (33.4\%) and non-specialist producers (31.6\%). In manufacturing have achieved 
$41.5 \%$ of the total non-specialist producers, while the mining industry in 2008 absorbed $29.6 \%$ vs. $23.2 \%$ in 2007 , and the production and supply of electricity and heat, $18.1 \%$.

Table no. 2

\section{Environmental protection expenditures in environmental areas and categories of producers in 2007 and 2008}

\begin{tabular}{|c|c|c|c|c|c|c|c|c|}
\hline \multirow{2}{*}{$\begin{array}{c}\text { Environmental } \\
\text { Domains }\end{array}$} & \multicolumn{2}{|c|}{ Total } & \multicolumn{2}{c|}{$\begin{array}{c}\text { Manufacturers } \\
\text { non-specialist }\end{array}$} & \multicolumn{2}{c|}{$\begin{array}{c}\text { Manufacturers } \\
\text { specialized }\end{array}$} & \multicolumn{2}{c|}{ Public Management } \\
\cline { 2 - 10 } & $\mathbf{2 0 0 7}$ & $\mathbf{2 0 0 8}$ & $\mathbf{2 0 0 7}$ & $\mathbf{2 0 0 8}$ & $\mathbf{2 0 0 7}$ & $\mathbf{2 0 0 8}$ & $\mathbf{2 0 0 7}$ & $\mathbf{2 0 0 8}$ \\
\hline Air Protection & 1.619 .272 & 1.130 .353 & 1.242 .606 & 803.990 & 55.984 & 44.614 & 320.682 & 281.749 \\
\hline Water Protection & 3.508 .767 & 2.697 .415 & 788.120 & 642.085 & 1.352 .751 & 1.002 .417 & 1.367 .896 & 1.052 .913 \\
\hline $\begin{array}{c}\text { Management } \\
\text { Waste }\end{array}$ & 8.927 .767 & 6.735 .353 & 1.072 .457 & 479.853 & 6.778 .036 & 5.843 .427 & 1.077 .274 & 412.073 \\
\hline $\begin{array}{c}\text { Soil and } \\
\text { Groundwater }\end{array}$ & 760.807 & 957.022 & 619.360 & 179.375 & 65.817 & 27.468 & 75.630 & 750.179 \\
\hline $\begin{array}{c}\text { Fighting } \\
\text { noise and } \\
\text { Vibration }\end{array}$ & 32.594 & 92.134 & 8.900 & 19.093 & 3.165 & 19.728 & 20.529 & 53.313 \\
\hline $\begin{array}{c}\text { Protection } \\
\text { natural resources } \\
\text { and conservation } \\
\text { biodiversity }\end{array}$ & 212.147 & 259.676 & 141.974 & 117.202 & 21.900 & 39.384 & 48.273 & 103.090 \\
\hline $\begin{array}{c}\text { Other areas } \\
\text { Environment }\end{array}$ & 1.416 .737 & 825.343 & 643.107 & 501.824 & 50.582 & 62.316 & 723.048 & 261.203 \\
\hline
\end{tabular}

Source: www.insse.ro

In environmental areas, specialist producers recorded the largest expense for waste management (approximately $76 \%$ of total expenditure for this area). For water protection, the largest expenditure was made by the government (39.0\%), while for air protection higher costs were recorded in $76.7 \%$ non-specialist producers.

Specialist producers recorded in 2007, the largest expenditure in the "waste management" (83.0\%), while for non-specialist producers, the costs have been directed primarily to the "air protection" (29.3\%). Government has made the biggest expenses on the "water protection" (36.1\%).

The accounting treatment of environmental expenditure is influenced by tax legislation in force. Romania Tax Code treats the expenditure for environmental protection and resource conservation as deductible expenses. Thus, entities will increase pollution prevention activities where the costs of these activities are deductible. Some expenses such as fines for violation of environmental regulations and certain remedial costs are not tax deductible. Entities will seek to reduce costs and fines and penalty tax deductible and will increase the number of environmental activities, which makes the tax treatment to be an important tool in changing attitudes towards environmental entity. 


\section{The potential of environmental management accounting to reflect environmental costs}

The concepts of "General Accounting" and "Analytical Accounting" are recognized by experts for a long time. Today, the practice tends to enshrine the names of "Financial Accounting" and "management accounting" or "managerial accounting".

Financial accounting records flows of an economic entity and its environment, expressed in the published financial statements, is governed by standards and regulations, providing information to external users. Financial accounting includes most environmental costs along with other costs, and thus environmental costs cannot be identified. To reduce pollution, some entities granted significant sums. In some cases they are easily identifiable, but environmental costs are much higher than those relating to pollution prevention and control, and are often included in hidden costs. Management accounting is an "internal accounting" providing information to internal users. As in all cases, environmental management accounting is a tool to inform managers about the environmental costs, to quantify the environmental effects of the entity. It appeared as a result of increasing pressure on the entity's management to reduce costs and minimize environmental impact activities (United Nations for Sustainable Development Division, 2003).

Unlike financial accounts using only monetary standard, management accounting does not resume only to the monetary standard it presents information in natural standard.

There are many definitions of environmental management accounting, but from an accounting perspective is important to see the offer of information on the entity's environmental performance made available to users. IFAC defines environmental management accounting as economic and environmental performance management by developing and implementing appropriate systems and practices on the environment. Although this includes reporting and auditing work in some entities, management accounting environment refers to the lifetime costs to determine total costs and benefits assessment strategic environmental management planning.

Department of Sustainable Development defines environmental management accounting as the accounting where the information given is used for internal organization of the decision making process, and the procedures taken for internal decisions include quantitative information on material and energy consumption, their flows, waste generated and monetary information on costs, savings and revenues on an activity with potential environmental impact.

Australian Environment Agency defines environmental management accounting as the identification, collection, analysis, internal reporting and using information on material and energy flows, environmental costs and other costs necessary for decision making within an entity.

From our point of view, environmental management accounting is a mechanism in which there are both financial and non-financial information, using tools such as calculation of environmental costs or environmental performance evaluation. Basically we are dealing with a blend of environmental management, management accounting, and the result providing information to internal users in order to take decisions regarding the environmental impact of the entity.

In some works, from the fact that this module called environmental management accounting provides financial and non-financial information, it appears the possibility of the division of environmental management accounting for money (Monetary Environmental Management Accounting MEMA) and accounting environmental management in physical units (Physical Environmental Management Accounting - PEMA).

Environmental management accounting in monetary units (MEMA) is used for internal management decisions and aims to identify and treat costs and benefits arising from the impact it has on the environment entity (Schaltegger and Wagner, 2005). With regard to his methods, MEMA is based on traditional management accounting adapted to be applied to the environmental aspects of 
corporate activity. It focuses on environmental impact assessment expressed in monetary terms (cost of fines for violation of the environment rules, investment in pollution prevention projects). Environmental management accounting in physical units (PEMA) serves as a informational tool for internal management decisions, using monetary data, expressed in physical units $(\mathrm{kg}, \mathrm{t}, \mathrm{m}$, etc.).

There is a very eloquent structuring data provided by environmental management accounting (EMA) and their application in so-called past and future-oriented tools:

Table no.3

Past and future oriented EMA tools

\begin{tabular}{|c|c|c|c|}
\hline \multicolumn{4}{|c|}{ EMA } \\
\hline \multicolumn{2}{|c|}{ MEMA } & \multicolumn{2}{|c|}{ PEMA } \\
\hline Past oriented tools & Future oriented tools & Past oriented tools & Future oriented tools \\
\hline $\begin{array}{l}\text { Annual environmental } \\
\text { expenditure or costs, } \\
\text { transition from } \\
\text { bookkeeping and cost } \\
\text { accounting }\end{array}$ & $\begin{array}{l}\text { Monetary } \\
\text { environmental } \\
\text { budgeting and } \\
\text { investment } \\
\text { appraisal }\end{array}$ & $\begin{array}{l}\text { Material, energy and } \\
\text { water } \\
\text { flow balances }\end{array}$ & $\begin{array}{l}\text { Physical environmental } \\
\text { budgeting and } \\
\text { investment } \\
\text { appraisal }\end{array}$ \\
\hline & $\begin{array}{l}\text { Calculating costs, } \\
\text { savings } \\
\text { and benefits of projects }\end{array}$ & $\begin{array}{l}\text { Environmental } \\
\text { performance } \\
\text { evaluation and } \\
\text { indicators, } \\
\text { benchmarking }\end{array}$ & $\begin{array}{l}\text { Setting quantified } \\
\text { performance targets }\end{array}$ \\
\hline $\begin{array}{l}\text { External disclosure of } \\
\text { environmental } \\
\text { expenditures, } \\
\text { investments and } \\
\text { liabilities }\end{array}$ & & $\begin{array}{l}\text { External environmental } \\
\text { reporting and other } \\
\text { reporting } \\
\text { to agencies and } \\
\text { authorities }\end{array}$ & $\begin{array}{l}\text { Design and } \\
\text { implementation } \\
\text { of environmental } \\
\text { management systems, } \\
\text { cleaner production, } \\
\text { pollution } \\
\text { prevention, design for } \\
\text { environment, supply } \\
\text { chain } \\
\text { management, etc. }\end{array}$ \\
\hline
\end{tabular}

Source: United Nations Division for Sustainable Development, Environmental Management Accounting, New York, 2001, http://www.un.org/esa/sustdev/publications/proceduresandprinciples.pdf, p.18

Data provided by environmental management accounting (EMA) and can structure their application in past and future-oriented tools: 
Table no. 4

Levels for the implementation of EMA

\begin{tabular}{|c|c|c|c|}
\hline \multicolumn{2}{|c|}{ Accounting in Monetary Units } & \multicolumn{2}{|c|}{ Accounting in Physical Units } \\
\hline \multirow{2}{*}{$\begin{array}{l}\text { Conventional } \\
\text { Accounting }\end{array}$} & \multicolumn{2}{|c|}{ Environmental Management Accounting } & \multirow{2}{*}{$\begin{array}{c}\text { Other Assessment } \\
\text { Tools } \\
\end{array}$} \\
\hline & MENA & PEMA & \\
\hline \multicolumn{4}{|c|}{ DATA ON THE CORPORATE LEVEL } \\
\hline $\begin{array}{l}\text { Conventional } \\
\text { bookkeeping }\end{array}$ & $\begin{array}{l}\text { Transition of } \\
\text { environmental part } \\
\text { from } \\
\text { bookkeeping and cost } \\
\text { accounting }\end{array}$ & $\begin{array}{l}\text { Material flow balances } \\
\text { on } \\
\text { the corporate level for } \\
\text { mass, energy and water } \\
\text { flows }\end{array}$ & $\begin{array}{l}\text { Production planning } \\
\text { systems, } \\
\text { stock accounting } \\
\text { systems }\end{array}$ \\
\hline \multicolumn{4}{|c|}{ DATA ON THE PROCESS/COST CENTRE AND PRODUCT/COST CARRIER LEVELS } \\
\hline Cost accounting & $\begin{array}{l}\text { Activity based material } \\
\text { flow cost accounting }\end{array}$ & $\begin{array}{l}\text { Material flow balances } \\
\text { on the process and } \\
\text { product levels }\end{array}$ & $\begin{array}{l}\text { Other environmental } \\
\text { assessments, measures } \\
\text { and evaluation tools }\end{array}$ \\
\hline \multicolumn{4}{|c|}{ BUSINESS APPLICATION } \\
\hline $\begin{array}{l}\text { Internal use for } \\
\text { statistics, } \\
\text { indicators, calculating } \\
\text { savings, budgeting and } \\
\text { investment appraisal }\end{array}$ & $\begin{array}{l}\text { Internal use for } \\
\text { statistics, } \\
\text { indicators, calculating } \\
\text { savings, budgeting and } \\
\text { investment appraisal of } \\
\text { environmental costs }\end{array}$ & $\begin{array}{l}\text { Internal use for } \\
\text { environmental } \\
\text { management systems } \\
\text { and } \\
\text { performance } \\
\text { evaluation, } \\
\text { benchmarking }\end{array}$ & $\begin{array}{l}\text { Other internal use for } \\
\text { cleaner production } \\
\text { projects } \\
\text { and condensing }\end{array}$ \\
\hline $\begin{array}{l}\text { External financial } \\
\text { reporting }\end{array}$ & $\begin{array}{l}\text { External disclosure of } \\
\text { environmental } \\
\text { expenditures, } \\
\text { investments and } \\
\text { liabilities }\end{array}$ & $\begin{array}{l}\text { External reporting } \\
\text { (EMA statement, } \\
\text { corporate } \\
\text { environmental report, } \\
\text { sustainability report) }\end{array}$ & $\begin{array}{l}\text { Other external reporting } \\
\text { to } \\
\text { statistical agencies, } \\
\text { local } \\
\text { governments, etc. }\end{array}$ \\
\hline \multicolumn{4}{|c|}{ NATIONAL APPLICATION } \\
\hline $\begin{array}{l}\text { National income } \\
\text { accounting by } \\
\text { statistical agency }\end{array}$ & $\begin{array}{l}\text { National accounting on } \\
\text { investments and annual } \\
\text { environmental costs of } \\
\text { industry, externalities } \\
\text { costing }\end{array}$ & $\begin{array}{l}\text { National resource } \\
\text { accounting } \\
\text { (material flow balances } \\
\text { for } \\
\text { countries, regions and } \\
\text { sectors) }\end{array}$ & \\
\hline
\end{tabular}

Source: United Nations Division for Sustainable Development, Environmental Management Accounting, New York, 2001, http://www.un.org/esa/sustdev/publications/proceduresandprinciples.pdf, p.19

It results from the above quite clearly the ability of environmental management accounting to reflect environmental costs that the entity is to prevent, treat or repair the damage it has caused to the environment. This is achieved via accounts available. As for traditional accounting management for each product or service work is necessary to calculate costs of production per unit of measure, and for environmental management accounting should be made to calculate average costs per average sequence performed on each sub domain environment. For example, with account 921 "core business expenses" under traditional management accounting is analytically distinct record for each department and each 
product consumption of raw materials and supplies made with the new product, the salary costs of staff involved in production, and in environmental management accounting would be detailed every activity undertaken in order to know at any moment average costs for the work done by the entity.

\section{Conclusions and proposals}

Of the presented one can see that accounting development in recent years, were focused on environmental accounting, accounting research in the field of environmental accounting have been and continue to the detriment of social accounting research; environmental financial accounting, environmental reporting continues to represent the principal interest in research in environmental accounting, but we noticed a growing interest to other sub domains such as environmental management accounting, environmental audit; in terms of research in Romania on environmental accounting, these are still early but however it is noted an interest in this area.

Chart of accounts applicable to entities that do not contain separate accounts to reflect environmental issues. Entities whose activities pollute should record separately the expenses incurred for the purchase of machinery and equipment used for environmental protection, their depreciation, with the salaries of staff involved in environmental protection, materials used and other environmental costs.

Basically, as currently reflected, Romanian accounting techniques is not possible to separate coverage of environmental issues in accounting. As opportunities for coverage of environmental issues in accounting such as development plan accounts in the accounts of grade 2 and 3 , by introducing new accounts, chart of accounts is not having a limited character. Another possibility is the organization of environmental management accounting, in this situation the development plan accounts are not required but finding the appropriate method of calculation.

Neither the management accounting practice is not too rich in terms of coverage of environmental issues; environmental costs are included along with other expenses. The only area where there seems to be concern for environmental management accounting is the mining, because of its complexities. At least at the legislative level, there is mandatory coverage of environmental costs in accounting.

Given the intense process of normalization and standardization of accounting, it is noted that in regard to environmental management and protection of it, efforts are made to a common representation of such activities, the existence of standards governing environmental issues such as as for Bulgaria, and Romania with the entry into force of the Order 3055/2009, makes itself felt in our accounting involvement in covering environmental issues. Due to the fact that in Bulgaria there is an international standard for environmental accounts entitled "Reporting on environmental regeneration," our proposal is to develop in Romania such a standard that deals with environmental issues and lines of coordination to be made in application.

The conclusion to be drawn is that we have to make the whole activity to be undertaken in full harmony with the environment, ensuring sustainable development.

\section{References}

1. Bețianu, L., 2009. Calitate totală în contabilitatea mediului, Universității „Alexandru Ioan Cuza" Publishing House, Iaşi.

2. Bețianu, L., Georgescu, I., 2008. Approaches of environmental information audit in annual reports, Annales Universitatis Apulensis Series Oeconomica, no.10 (1).

3. Caraiani, C., Jianu, I., 2007. Contabilitatea verde - o perspectivă a schimbării în contabilitate, Revista CECCAR, Partea I - a, nr. 4/2007. 
4. Cenuşă, L., 2008. Contabilitatea verde - un pas important spre o reală protecție a mediului, Revista CECCAR, nr. 2/2008.

5. Dimităr, J., 2009. Contabilitatea poate şi trebuie să fie implicată în protecția mediului, Revista Audit Financiar nr.12/2009; pp. 50-55;

6. Dumitrana, M., 2005. Contabilitate şi Informatică de Gestiune Journal, nr. 13-15/2005.

7. Gamini, H., 2005. Sustainable development and environmental accounting: the challenge to the economics an accounting profession, Internationl Journal of Social Economics, vol.32.

8. Jahamani,Y. F., 2003. Green accounting in developing countries: the case of U.A.E. and Jordan, Managerial Finance Journal, Vol. 29, Issue: 8.

9. Ienciu, A., 2009. Implicațiile problemelor de mediu în contabilitatea şi auditul situațiilor financiare, Risoprint Publishing House, Cluj Napoca.

10. Lafontaine, J.P., 2002. Enseignement et management de l'information: le cas de la comptabilite environnementale, XXIII congres de l' AFC, Toulouse.

11. Maunders, K. T., Burrit, R. L., 1991. Accounting and Ecological Crisis, Accounting, Auditing \& Accountability Journal, Vol. 4 Issue: 3.

12. Perez, E.A., Ruiz, C., Fenech, F., 2007. Environmental management systems as an embedding mechanism a research note, Accounting, Auditingand Accountability Journal, vol.20.

13. Schaltegger, S., 2004, Sustainability Accounting and Reporting - Fashion or Durable? 7th EMAN conference on Sustainability Accounting and Reporting Lüneburg.

14. Schaltegger, S., Wagne, M., 2005. Current Trends in Environmental Cost Accounting - and its interaction with eco-efficiency performance measurement and indicators, Eco-efficiency in industry an science, vol.18.

15. Tabără, N., Horomnea. E., Nuţă, F. M., 2007. Dezvoltarea durabilă şi contabilitatea de mediu, Revista Finanțe Publice şi Contabilitate, nr. 9/2007.

16. Todea, N., 2009. Teorie contabilă şi raportare financiară, Aeternitas Publishing House, Alba Iulia.

17. Canadian Institute of Chartered Accountants, 1998. Examination of national standards and regulations for environmental financial accounting

18. Environment and the OECD Guidelines for Multinational Enterprises: Corporate Tools and Approaches Publication: Paris, OECD, 2005.

19. Ordinului 3055/2009 pentru aprobarea Reglementărilor Contabile conforme cu Directivele Europene, Publicat în Monitorul Oficial al României nr. 766/10.11.2009.

20. United Nations Division for Sustainable Development, Environmental Management Accounting, New York, 2001, available on-line at http://www.un.org/esa/sustdev/publications/proceduresandprinciples.pdf.

21. www.insse.ro, accessed May 20, 2010. 